\title{
Prostate cancer and acromegaly
}

\author{
Câncer de próstata e acromegalia
}

Lívia L. Corrêa ${ }^{1,2}$, Giovanna A. Balarini Lima ${ }^{1,2}$, Helena B. de

Melo Paiva', Cíntia M. dos Santos Silva', Suzana A. Cavallieri ${ }^{3}$,

Luiz Carlos D. de Miranda ${ }^{4}$, Mônica R. Gadelha ${ }^{1,2}$

\begin{abstract}
Acromegalic patients have an increased prevalence of prostatic disorders compared to agematched healthy subjects. Increased size of the whole prostate or the transitional zone, together with an elevated incidence of other structural changes, such as nodules, cysts, and calcifications, have been reported. Prostate enlargement in young acromegalic patients with low testosterone levels due to central hypogonadism supports the hypothesis that chronic GH and IGF-I excess cause prostate hyperplasia. The relationship between prostatic carcinoma and acromegaly is, until now, only circumstantial. Long-term follow-up of these patients is necessary since epidemiologic studies showed association between serum IGF-I levels in the upper normal limit and prostate cancer in the general population. This review approaches prostate diseases in patients with acromegaly. Arq Bras Endocrinol Metab. 2009;53(8):963-8

Keywords

Acromegaly; prostate; cancer
\end{abstract}

\section{RESUMO}

Pacientes com acromegalia têm uma prevalência aumentada de desordens prostáticas em comparação a controles saudáveis da mesma idade. Aumento do tamanho de toda a próstata ou da zona de transição, juntamente com uma incidência elevada de outras alterações estruturais, como nódulos, cistos e calcificações, foi descrito. $\mathrm{O}$ aumento da próstata em acromegálicos jovens e com níveis baixos de testosterona devido ao hipogonadismo central sugere que o excesso crônico do GH e do IGF-I cause hiperplasia prostática. A relação entre câncer de próstata e acromegalia é, até o momento, apenas circunstancial. Entretanto, um seguimento prolongado desses pacientes é necessário uma vez que estudos epidemiológicos reportaram uma associação entre níveis séricos de IGF-I no limite superior da normalidade e câncer de próstata na população geral. Esta revisão aborda as patologias prostáticas em pacientes com acromegalia. Arq Bras Endocrinol Metab. 2009;53(8):963-8

Descritores

Acromegalia; próstata; câncer

\author{
${ }^{1}$ Serviço de Endocrinologia, \\ Hospital Universitário Clementino \\ Fraga Filho (HUCFF), Universidade \\ Federal do Rio de Janeiro (UFRJ), \\ Rio de Janeiro, RJ, Brasil \\ ${ }^{2}$ Instituto Estadual de Diabetes \\ e Endocrinologia (IEDE), Rio \\ de Janeiro, RJ, Brasil \\ ${ }^{3}$ Labs D'Or Laboratório e Imagem, \\ Rio de Janeiro, RJ, Brasil \\ ${ }^{4}$ Serviço de Urologia, Hospital \\ Universitário Clementino Fraga \\ Filho (HUCFF), Universidade \\ Federal do Rio de Janeiro (UFRJ), \\ Rio de Janeiro, RJ, Brasil
}

Correspondence to: Mônica R. Gadelha Rua Nascimento Silva, 555, ap. 101 - Ipanema 22421-020 - Rio de Janeiro, RJ, Brasil

mgadelha@hucff.ufr..br

Received on July/11/2009 Accepted on Nov/7/2009

\section{INTRODUCTION}

A cromegaly is a rare disease usually caused by a growth hormone $(\mathrm{GH})$ secreting pituitary adenoma $(1,2)$. The growth effects of $\mathrm{GH}$ are primarily mediated through the hepatic production of insulin-like growth factor I (IGF-I), which has a central role in regulating cell proliferation and differentiation (1). Active acromegaly is associated with increased morbidity and mortality, mainly due to cardiovascular, cerebrovascular and respiratory diseases $(3,4)$. In addition, almost $20 \%$ of the deaths occurrences among acromegalic patients are attributa- ble to malignancy $(5,6)$; nonetheless, the relationship between acromegaly and cancer risk remains controversial $(6,7)$.

Acromegalic patients have an increased prevalence of prostatic disorders compared to age-matched healthy subjects. Increased size of the whole prostate or the transitional zone, together with an elevated incidence of other structural changes, such as nodules, cysts, and calcifications, were shown in a large proportion of patients $(8,9)$.

The relationship between prostatic carcinoma and acromegaly is circumstantial (10) probably because 
acromegaly is a rarely diagnosed disease, which makes it difficult for single centers to bring together significant number of patients for statistical analysis. Furthermore, this cancer is usually limited to elderly men, and only nowadays, with improved treatment of acromegaly and of the other complications, acromegalic patients are surviving long enough to reach the age of increased cancer risk (10).

\section{PROSTATE DISEASES}

Prostate enlargement starts approximately at the age of 40 (11) and develops almost exclusively in the transition and periurethral zones (12). Benign prostate hyperplasia is a progressive and prevalent disease. It is estimated that $50 \%$ and $90 \%$ of the men with respectively 50 and 80 years of age present histological evidences of prostate hyperplasia (13). The mean prostate volume was reported as $30 \mathrm{~mL}$ in a normal population of $181 \mathrm{men}$, aged from 40 to 79 years (14). The accepted criteria for benign prostate hyperplasia is a prostate volume greater than $30 \mathrm{~mL}(12)$. No data is available in normal men younger than 40 years old.

After nonmelanoma skin cancer, prostate cancer represents the most frequently diagnosed cancer in adult men and is the second cause of death due to cancer among Brazilian men (15). The annual incidence is approximately 50 cases per 100.000 men (15).

\section{IGF-I AND PROSTATE DISEASES}

The physiological development and growth of the prostate have been shown to depend on testosterone and dihydrotestosterone (DHT), a more potent 5 alfareduced metabolite, which seem to be the leading factors in stimulating benign and malignant prostatic disorders (16). However, androgens action alone seems to be insufficient to explain prostatic diseases $(11,16)$. The existence of important cross-talk among androgens, growth factors and IGF binding proteins (IGFBPs) at prostatic level has been suggested (17).

Both IGF-I and IGF-II have direct mitogenic effects on several tissues, including normal and tumoral prostate epithelial cells, and have been implicated in the pathogenesis of prostate cancer $(18,19)$. They exert the mitogenic action by stimulating the cell cycle progression (20). In addition, IGF-I also inhibits apoptosis (21). The actions of IGF-I on cell proliferation and apoptosis are mediated via a specific cell-membra- ne receptor, IGF-I receptor (IGF-IR), which contains tyrosine kinase activity $(22,23)$.

In a retrospective review of nonacromegalic men, those with prostate carcinoma proven to be histological were found to have serum IGF-I levels higher than control group, although still within the normal range $(19,24)$. The relative risk was estimated at 1.9 for each $60 \mathrm{mg} / \mathrm{mL}$ increment in serum IGF-I, although increased almost 7 -fold in the presence of a higher serum testosterone level, as during testosterone replacement therapy (24). These findings were supported by a prospective epidemiological study in which Chan and cols. (18) found a 4 times increased risk of developing prostate cancer in men with IGF-I levels in the upper quartile of the normal range, compared to men with IGF-I in the lowest quartile, seven years before the cancer was clinically apparent and also found a 5 -fold increased risk of advanced stage prostate cancer (25). This risk was increased to almost 18 times in men aged over 60 years (18).

A recent analysis based on individual patient data from 12 prospective studies ( $\mathrm{n}=3,700$ prostate cancer cases) found an increased prostate cancer risk in the highest compared to the lowest quintiles of IGF-I (odds ratio, $\mathrm{OR}=1.38$, confidence interval, $\mathrm{CI}=1.19$ 1.60) (26). A meta-analysis of nine prospective studies, that included 1,512 men with prostate cancer, found a similar risk $(\mathrm{OR}=1.31 ; \mathrm{CI}=1.03-1.71)(27)$. This association with IGF-I was weaker than that reported in an earlier meta-analysis that estimated a summary OR of $1.83(\mathrm{CI}=1.03-3.26)$ for the association of the uppermost categories of serum IGF-I compared to the lowermost (28). Finally, Shi and cols. (29), analyzing 14 case-control studies, reported an OR of 1.47 for higher IGF-I (CI = 1.27-1.71) (Table 1). All studies were consistent with higher circulating levels of IGF-I, conferring an increased risk of prostate cancer.

The largest review analyzing the association between IGF-I and prostate cancer was published in 2009 (30). This meta-analysis revealed that the published literature is consistent with an average $21 \%$ increase risk of prostate cancer per standard deviation increase in IGF-I. They also showed a stronger association of IGF-I with more aggressive and advanced cancers, compared to nonaggressive and localized (30). This finding could imply that the IGF-I system plays a more relevant role in cancer progression than in cancer initiation. Mouse models of prostate cancer have shown that progression from androgen-dependence to androgen-independence is associated with a major increase in IGF-I gene expression, 
Table 1. Meta-analyses of serum IGF-I levels (comparison of highest and lowest) and prostate cancer risk

\begin{tabular}{lcc}
\hline Author & Studies included & OR (95\% Cl) \\
\hline Shi and cols., 2001 (29) & 14 & $1.47(1.27-1.71)$ \\
Renehan and cols., 2004 (28) & 6 & $1.83(1.03-3.26)$ \\
Morris and cols., 2006 (27) & 9 & $1.31(1.03-1.67)$ \\
Roddam and cols., 2008 (26) & 12 & $1.38(1.19-1.60)$ \\
Rowlands and cols., 2009 (30) & 42 & $1.21(1.07-1.36)$ \\
\hline
\end{tabular}

OR: odds ratio; Cl: confidence interval.

which supports the potential of IGF-I as a biomarker of more aggressive cancer (31). Therefore, the IGF system will probably become a potential therapeutic target, either alone or in combination with other chemotherapeutic agents, for the treatment of prostate cancer (30).

A possible explanation for variability in normal IGF-I levels was recently proposed. Johansson and cols. (32) hypothesized that genetic variation in the 3' region of the IGF-I gene influences levels of circulating IGF-I and, therefore, prostate cancer risk.

The interaction between IGF-I and IGF-IR is regulated by the IGFBPs. The most abundant of the six known IGFBPs found in the circulation is IGFBP-3, a potent inhibitor of IGF-I action $(33,34)$. At the tissue level, IGFBP-3 regulates the mitogenic activity and inhibits the anti-apoptotic effect of IGF-I (34). In addition to its role as an IGF-I modulator, IGFBP-3 has been linked to induction of apoptosis $(35,36)$. The levels of IGFBP- 2 and IGFBP- 3 are also found to be altered in the serum and prostate tissue of prostate cancer patients. In these patients, levels of IGFBP-2 are often increased, whereas levels of IGFBP- 3 are often decreased (37-39). Recently, the meta-analysis of Rowlands and cols. (30) found that the association between IGFBP-3 and prostate cancer was inconsistent. In addition, the authors showed little evidence for a role of IGF-II, IGFBP-1 or IGFBP-2 in prostate cancer risk. Since IGFBP-3 is a substrate for PSA, a member of the kallikrein family of serine proteases, it is postulated that rising PSA levels during the natural history of prostate cancer facilitates disease progression by proteolytically cleaving IGFBP-3, thereby increasing the level of bioavailable IGF-I at the cellular level (40).

\section{PROSTATE DISEASES IN ACROMEGALIC PATIENTS}

It is well known that $\mathrm{GH}$ promotes a stimulatory effect on both IGF-I and IGFBP-3. IGF-I stimulates cell proliferation and growth advantage (20), however,
IGFBP-3 stimulates apoptosis and consequently arrests cell growth (35). Thus, GH excess, increasing both IGF-I and IGFBP-3 levels, promotes deregulated cell growth balance characterized by dynamic signals for cell growth advantage and cell apoptosis (41).

Several epidemiologic studies have suggested that high-normal serum IGF-I levels may be concordant with a higher risk of prostate cancer in the general population, and that high-normal serum IGFBP-3 levels are concordant with a lower risk $(18,19,24,28)$. Since acromegalic patients exhibit both elevated, IGF-I and IGFBP-3 levels, their relative risk for cancer development seems to be lower than expected (4l).

Significant prostate enlargement has been demonstrated in young (age below 40 years old) patients with acromegaly and hypogonadism, as compared to age-matched controls, with a prevalence of micro and macro-calcifications higher than expected $(8,42)$. The presence of prostate disorders in young acromegalic, in whom we did not expect to have age-dependent prostate diseases, and in presence of hypogonadism supports the hypothesis that chronic GH/IGF-I excess causes prostate hyperplasia $(8,9,43)$. Suppression of $\mathrm{GH}$ and IGF-I levels by surgery or somatostatin analogs inducing a significant decrease in prostate volume, despite a possible increase in androgen levels during acromegaly treatment, confirms this hypothesis $(8,43)$.

Prostate epithelial cells express IGF-IR mRNA and IGF-I stimulation increases stromal cell density by $80 \%$, providing a possible explanation for the abovementioned association of acromegaly with benign prostate hyperplasia (44). Even though acromegaly is associated with benign prostate hyperplasia as well as micro and macro-calcifications regardless of age or gonadal status $(8,9)$, the incidence of prostate cancer in patients with acromegaly is not elevated $(6,45)$. It has been argued that this incidence may be seen because prostate cancer is limited to elderly men and only recently men with acromegaly have survived long enough to participate in epidemiologic studies (10).

Nabarro (3) showed one prostate cancer in a group of 133 men. The men prostate cancer incidence rate found by the author was almost the same as expected from registrations in England and Wales for the year 1980. Cheung and Boyages (46) described no significant increase in cancer risk for men ( 1 prostate cancer case in 29 male patients) although statistical power of such study has been questioned. Colao and cols. (9) studied 46 acromegalics, aged from 26 to 74 (50.5 \pm 
2.2) years and 30 age-matched controls. No abnormality of prostate structure was detected in 10 of 46 patients. Prostate hyperplasia was reported in 27 patients (59\%) and eight controls (27\%). Calcifications were detected in 28 acromegalic patients (61\%) and seven controls $(23 \%)$, cysts were found in 12 patients $(26 \%)$ and clear-cut nodules in six patients (13\%). None of the patients and controls presented prostate cancer. They concluded that acromegalic patients have an increased prevalence of prostate disorders in comparison to agematched control subjects mainly because of increased transitional zone and prostate volumes and elevated incidence of nodules and calcifications. Baris and cols. (45) found that prostate cancer risk was slightly, but non-significantly, elevated, mainly among men 70 years old or older (Table 2).

An important consideration is that acromegalic patients presenting cancer before the diagnosis of acromegaly are usually excluded from the epidemiological studies. It is interesting to point out that an established cancer in a patient with acromegaly and uncontrolled GH and IGF-I levels are likely to be more aggressive, with potentially increased cancer-associated morbidity and mortality (41).

Recently, we studied 35 male acromegalic patients, aged from 24 to $69(45.4 \pm 11.6)$ years with transrectal ultrasonography. This was the first Brazilian study that assessed prostate diseases in patients with acromegaly. It was performed after approval of the local ethics committee and once the patient's informed consent was obtained. We found 10 patients $(28 \%)$ with prostate hyperplasia and one cancer case $(2.8 \%)$ (Table 2 ). Probably, we found less prostate hyperplasia than Colao's group because our patients are younger. Calcifications were detected in 10 acromegalic patients $(28 \%)$, one of them younger than 40 years old, and cystic dilatations in
$5(14 \%)$. Analyzing patients according to age, $12(34 \%)$ were younger than 40 years old and prostate hyperplasia was not found. Four ( $40 \%)$ out of 10 patients with prostate hyperplasia were aged from 40 to 50 years old. Considering the gonadal status, 14 patients $(40 \%)$ were hypogonadic and were not receiving testosterone replacement due to severe sleep apnea. In this group, two (14\%) presented prostate enlargement. The patient with prostate cancer was 56 years old at diagnosis. He presented with clinical features of acromegaly and laboratory confirmation was done $[\mathrm{GH}=2.1 \mathrm{ng} / \mathrm{mL}$ and IGF-I = $747 \mathrm{ng} / \mathrm{mL}$ (normal value: $78-258 \mathrm{ng} / \mathrm{mL}$ )]. Octreotide LAR was started as primary therapy with biochemical control and, four months later, the cancer was diagnosed. He was not receiving testosterone replacement. Also, there was no family history of prostate cancer. After radical prostatectomy, goserelin was started with satisfactory disease control.

In summary, of the five studies shown in table 2, three $(3,45,46)$ assessed only the prevalence of prostate cancer in acromegalic patients. None found a significantly elevated cancer risk. From a total of 909 men studied, 15 cases were diagnosed. The other two studies (9, unpublished) evaluated the prevalence of cancer, hyperplasia and other prostatic diseases. One cancer case and 37 patients with prostate hyperplasia were found among 81 men.

The management of acromegaly may be surgery, medical therapy (dopamine agonists, somatostatin analogs and GH receptor antagonist) and/or radiotherapy. Somatostatin receptors, primarily subtypes 1 and 2 , were detected in stromal cells of benign and malignant prostate (47-49). Somatostatin analogs could act on prostate size by different mechanisms. It can induce a decrease in prostate dimension by displaying a direct antiproliferative effect and indirectly by suppressing cir-

Table 2. Studies of prostate diseases prevalence in acromegalic patients

\begin{tabular}{lcccc}
\hline Author & Male patients (n) & Hyperplasia (n) & Cancer (n) & Other \\
\hline Nabarro, 1987 (3) & 133 & NA & 1 & NA \\
Cheung and Boyages, 1997 (46) & 29 & NA & 1 & NA \\
Colao and cols. 1999 (9) & 46 & 27 & 0 & Calcifications: 28 \\
& Cysts: 12 & Nodules: 6 \\
Baris and cols., 2002 (45) & & & 13 & NA \\
Corrêa, 2009 (unpublished data) & 747 & NA & 1 & Calcifications: 10 \\
& 35 & 10 & & Cystic dilations: 5 \\
\hline
\end{tabular}

NA: not available. 
culating levels of GH/IGF-I (50). It may also prevent prostate enlargement by inducing apoptotic processes of the mesenchymal tissue and by modifying the hemodynamics of local blood circulation (51). The positive effect of somatostatin analogs treatment on prostate volume and morphology was observed despite a significant increase in testosterone levels. It should be mentioned that these drugs were employed together with complete androgen blockade in patients with prostate carcinoma, showing beneficial results $(52,53)$.

A similar approach was taken with $\mathrm{GH}$ receptor (GHR) antagonist pegvisomant. This molecule competes with the native $\mathrm{GH}$ and prevents $\mathrm{GH}$ receptor dimerization and, therefore, blockade of its signaling pathway (54). This leads to inhibition of IGF-I synthesis and secretion. It may potentially have therapeutic effects in the treatment of malignant diseases (55). These effects may, in part, be exerted indirectly through reduction in the levels of hepatic IGF-I, however, the main action in vivo appears to be the direct suppression of the autocrine and/or paracrine production of IGF-I and IGF-II in tumors (56). In vitro, pegvisomant inhibits the proliferation of prostatic cancer cells $(56)$.

In conclusion, chronic excess of GH and IGF-I causes prostate overgrowth and structural abnormalities, although the relationship between prostatic carcinoma and acromegaly, even in patients receiving testosterone replacement, is circumstantial. However, long-term follow-up of these patients is necessary since epidemiologic studies related high-normal plasma levels of IGF-I to prostate cancer in the general population $(18,19,24)$. In agreement with the literature, we suggest that men with acromegaly be carefully screened for prostate cancer as the general population (7). Measurement of serum PSA and rectal examination is recommendable annually $(7,57,58)$.

Disclosure: no potential conflict of interest relevant to this article was reported.

\section{REFERENCES}

1. Melmed S. Acromegaly. N Engl J Med. 1990;322:966-77.

2. Taboada GF, van Haute FR, Corrêa LL, Casini AF, Gadelha MR. Etiologic aspects and management of acromegaly. Arq Bras Endocrinol Metab. 2005;49(5):626-40.

3. Nabarro JDN. Acromegaly. Clin Endocrinol. 1987;26(4):481-512.

4. Bengtsson B, Eden S, Ernest I, Oden A, Sjogren B. Epidemiology and long-term survival in acromegaly. A study of 166 cases diagnosed between 1955 and 1984. Acta Med Scand. 1988;223(4):327-35.

5. Rajasoorya C, Holdaway IM, Wrightson P, Scott DJ, Ibbertson HK. Determinants of clinical outcome and survival in acromegaly. Clin Endocrinol. 1994;41(1):95-102.
6. Orme SM, Mcnally RJQ, Cartwright RA, Belchetz PE. Mortality and cancer incidence in acromegaly: a retrospective cohort study. J Clin Endocrinol Metab. 1998;83(8):2730-4.

7. Loeper S, Ezzat S. Acromegaly: re-thinking the cancer risk. Rev Endocr Metab Disord. 2008;9(1):41-58.

8. Colao A, Marzullo P, Ferone D, Spiezia S, Cerbone G, Marino V, et al. Prostatic hyperplasia: an unknown feature of acromegaly. $J$ Clin Endocrinol Metab. 1998;83(3):3775-9.

9. Colao A, Marzullo P, Spiezia S, Ferone D, Giaccio A, Cerbone G, et al. Effect of growth hormone $(\mathrm{GH})$ and insulin-like growth factor I on prostatic diseases: an ultrasonographic and endocrine study in acromegaly, GH deficiency, and healthy subjects. J Clin Endocrinol Metab. 1999;84(6):1986-91.

10. Jenkins PJ, Besser M. Clinical perspective: acromegaly and cancer: a problem. J Clin Endocrinol Metab. 2001;86(7):2935-41.

11. Wilson JD. The pathogenesis of benign prostatic hyperplasia. Am J Med. 1980;68(5):745-56.

12. Mc Neal JE. Normal histology of the prostate. Am J Surg Pathol. 1988;12(8):619-33.

13. Brum IS, Spritzer PM, Brentani MM. Molecular biology in the prostate neoplasia. Arq Bras Endocrinol Metab. 2005;49(5):797-804.

14. Collins GN, Raab GM, Hehir M, King B, Garraway WM. Reproducibility and observer variability of transrectal ultrasound measurements of prostatic volume. Ultrasound Med Biol. 1995;21(9):1101-5.

15. Instituto Nacional do Câncer (Inca). Ministério da Saúde, Brasil. [cited nov 8, 2009]. Available from: http://www.inca.gov.br.

16. Cuhna GR, Donjacour AA, Cooke PS, Mee S, Bigsby RM, Higgins $\mathrm{SJ}$, et al. The endocrinology and developmental biology of the prostate. Endoc Rev. 1987;8(3):338-62.

17. Motta M, Dondi D, Moretti RM, Marelli MM, Pimpinelli F, Maggi R, et al. Role of growth factors, steroid and peptide hormones in the regulation of human prostatic tumor growth. J Steroid Biochem Mol Biol. 1996;56(1-6):107-11.

18. Chan JM, Stampfer MJ, Giovannucci E, Gann PH, Ma J, Wilkinson $P$, et al. Plasma insulin-like growth factor-1 and prostate cancer risk: A Prospective Study. Science. 1998;279(5350):563-6.

19. Wolk A, Mantzoros CS, Andersson SO, Bergström H, Signorello LB, Lagiou P, et al. Insulin-like growth factor 1 and prostate cancer risk: a population-based, case-control study. J Natl Cancer Inst. 1998;90(12):911-5.

20. Qu BH, Karas M, Koval A, Le Roith D. Insulin receptor substrate-4 enhances insulin-like growth factor-l-induced cell proliferation. $J$ Biol Chem. 1999; 274(44):31179-84.

21. Panizas $M$, Sahiel AR, Le Roith $D$. Insulin-like growth factor I inhibits apoptosis using the phosphatidylinositol 3 'kinase and mitogen-activated protein kinase pathways. J Biol Chem. 1997;272(1):154-61.

22. LeRoith D, Werner H, Beitner-Johnston D, Roberts CT Jr. Molecular and cellular aspects of the insulin-like growth factor-l receptor. Endoc Rev. 1995;16(2):143-63.

23. LeRoith D. Regulation of proliferation and apoptosis by the insulin-like growth factor I receptor. Growth Horm IGF-I Res. 2000;10 Suppl A:S12-3.

24. Mantzoros CS, Tzonou A, Signorello LB, Stampfer M, Trichopoulos D, Adami HO. Insulin-like growth factor 1 in relation to prostate cancer and benign prostatic hyperplasia. $\mathrm{Br} \mathrm{J}$ Cancer. 1997;76(9):1115-8.

25. Chan JM, Stampfer MJ, Ma J, Gann P, Gaziano JM, Pollak M, et al. Insulin-like growth factor-I (IGF-I) and IFG binding protein-3 as predictors of advanced-stage prostate cancer. J Natl Cancer Inst. 2002;94(14):1099-106.

26. Roddam AW, Allen NE, Appleby P, KeyTJ, Ferrucci L, Carter HB, et al. Insulin-like growth factors, their binding proteins and prostate cancer risk: analysis of individual patient data from 12 prospective studies. Ann Intern Med. 2008;149(7):461-71. 
27. Morris JK, George LM, Wu T, Wald NJ. Insulin-like growth factors and cancer: no role in screening. Evidence from the BUPA study and meta-analysis of prospective epidemiological Studies. $\mathrm{Br} \mathrm{J}$ Cancer. 2006;95(1):112-7.

28. Renehan AG, Zwahlen M, Minder C, O'Dwyer ST, Shalet SM, Egger M. Insulin-like growth factor (IGF)-I, IGF binding protein-3, and cancer risk: systematic review and meta-regression analysis. Lancet. 2004;363(9418):1346-53.

29. Shi R, Berkel HJ, Yu H. Insulin-like growth factor-I and prostate cancer: a meta-analysis. Br J Cancer. 2001;85(7):991-6.

30. Rowlands M, Gunnell D, Harris R, Vatten LJ, Holly JMP, Matin RM. Circulating insulin-like growth factor peptides and prostate cancer risk: a systematic review and meta-analysis. Int J Cancer. 2009;124(10):2416-29.

31. NickersonT, Chang F, Lorimer D, Smeekens SP, Sawyers CL, Pollak $\mathrm{M}$. In vivo progression of $\mathrm{LAPC}-9$ and $\mathrm{LNCaP}$ prostate cancer models to androgen independence is associated with increased expression of insulin-like growth factor I (IGF-I) and IGF-I receptor (IGF-IR). Cancer Res. 2001;61(16):6276-80.

32. Johansson M, McKay JD, Wiklund F, Rinaldi $S$, Verheus $M$, van Gils $\mathrm{CH}$, et al. Implications for prostate cancer of insulin-like growth factor- I (IGF-I) genetic variation and circulating IGF-I levels. J Clin Endocrinol Metab. 2007;92(12):4820-6.

33. Jones JI, Clemmons DR. Insulin-like growth factors and their binding proteins: biological actions. Endocr Rev. 1995;16(1):3-34.

34. Baxter RC, Butt AJ, Schendlich LJ, Martin JL. Antiproliferative and pro-apoptotic activities of insulin-like growth factor binding protein-3. Growth Horm IGF-I Res. 2000;10 Suppl A:S10-1.

35. Butt AJ, Firth SM, Baxter RC. The IGF axis and programmed cell death. Immunol Cell Biol. 1999;77(3):256-62.

36. Rajah R, Valentinis B, Cohen P. Insulin-like growth factor (IGF)binding protein- 3 induces apoptosis and mediates the effects of transforming growth factor-beta 1 on programmed cell death through a p-53 and IGF-independent mechanism. J Biol Chem. 1997;272(18):12181-8.

37. Tennant MK, Thrasher JB, Twomey PA, Birnbaum RS, Plymate SR. Insulin-like growth factor-binding protein-2 and -3 expression in benign human prostate epithelium, prostate intraepithelial neoplasia and adenocarcinoma of the prostate. J Clin Endocrinol Metab. 1996;81(1):411-20.

38. Thrasher BJ, Tennant MK, Twomey PA, Hansberry KL, Wettlaufer $\mathrm{KL}$, Plymate SR. Immunohistochemical localization of insulin-like growth factor binding proteins 2 and 3 in prostate tissue: clinical correlations. J Urol. 1996;155(3):999-1003.

39. Kanety H, Madjar Y, Dagan $Y$, Levi J, Papa MZ, Pariente C, et al. Serum insulin-like growth factor-binding protein-2 (IGFBP-2) is increased and IGFBP-3 is decreased in patients with prostate cancer: correlation with serum prostate-specific antigen. J Clin Endocrinol Metab. 1993;77(1):229-33.

40. Cohen P, PeehI DM, Graves HCB, Rosenfeld RG. Biological effects of prostate specific antigen as an insulin-like growth factor binding protein-3 protease. J Endocrinol. 1994;142(3):407-15.

41. Melmed S. Acromegaly and cancer: not a problem? J Clin Endocrinol Metab. 2001;86(7):2929-34.

42. Colao A, Marzullo P, Spiezia S, Lombardi G. Acromegaly and prostate cancer. Growth Horm IGF-I Res. 2000;suppl A:S37-8.
43. Colao A, Marzullo P, Spiezia S, Giaccio A, Ferone D, Cerbone G, et al. Effect of two years of growth hormone and insulin-like growth factor-l supresion on prostate diseases in acromegalic patients. $J$ Clin Endocrinol Metab. 2000;85(10):3754-61.

44. Grant ES, Ross MB, Ballard S, Naylor A, Habib FK. The insulin-like growth factor type 1 receptor stimulates growth and suppresses apoptosis in prostatic stromal cells. J Clin Endocrinol Metab. 1998;83(9):3252-7.

45. Baris D, Gridley G, Ron E, Weiderpass E, Mellemkjaer L, Ekbom A, et al. Acromegaly and cancer risk: a cohort study in Sweden and Denmark. Cancer Causes Control. 2002;13(5): 395-400.

46. Cheung NW, Boyages SC. Increased incidente of neoplasia in females with acromegaly. Clin Endocrinol. 1997;47(3):323-7.

47. Reubi JC, Waser B, Schaer JC, Markwalder R. Somatostatin receptors in human prostate and prostate cancer. J Clin Endocrinol Metab. 1995;80(9):2806-14.

48. Tatoud R, Degeorges A, Prévost G, Hoepffner JL, Gauvillé C, Millot $\mathrm{G}$, et al. Somatostatin receptor in prostate tissue and derived cell cultures, and the in vitro growth inhibitory effect of BIM23014 analog. Mol Cell Endocrinol. 1995;113(2):195-204.

49. Sinisi AA, Bellastella A, Prezioso D, Nicchio MR, Lotti T, Salvatore $M$, et al. Different expression patterns of somatostain receptor subtypes in cultered epithelial cells from human normal prostate and prostate cancer. J Clin Endocrinol Metab. 1997;82(8):2566-9.

50. Hofland LJ, van Koetsveld PM, Wouters N, Waaijers M, Reubi JC, Lamberts SW. Dissociation of antiproliferative and antihormonal effects of the somatostatin analog octreotide on $7315 \mathrm{~b}$ pituitary tumor cells. Endocrinology. 1992;131(2):571-7.

51. Reubi JC, Schaer JC, Laissue JA, Waser B. Somatostatin receptors and their subtypes in human tumors and peritumoral vessels. Metab Clin Exp. 1996;45(1):39-41.

52. Sciarra A, Panebianco V, Ciccariello M, Salciccia S, Gentilucci A, Lisi $D$, et al. Complete response to the combination therapy with androgen blockage and somatostatin analogue in a patient with advanced prostate cancer: magnetic resonance imaging with $1 \mathrm{H}$ spectroscopy. Eur Urol. 2008;53(3):652-5.

53. Vainas G, Pasaitou V, Galaktidou G, Maris K, Christodoulou K, Costantinidis $\mathrm{C}$, et al. The role of somatostatin analogues in complete antiandrogen treatment in patients with prostatic carcinoma. J Exp Clin Cancer Res. 1997;16:199-226.

54. Kopchick JJ, Parkinson C, Stevens EC, Trainer PJ. Growth hormone receptor antagonist: discovery, development, and use in patients with acromegaly. Endocr Rev. 2002;23(5):623-46.

55. Yakar S, LeRoith D, Brodt P. The role of the growth hormone/ insulin-like growth factor axis in tumor growth and progression: Lessons from animal models. Cytokine Growth Factor Rev. 2005;16(4-5):407-20.

56. Schally AV, Varga JL. Antagonistic analogs of growth hormonereleasing hormone: new potential antitumor agents. Trends Endocrinol Metab. 1999;10(10):383-91.

57. Webb SM, Casanueva F, Wass JAH. Oncological complications of excess GH in acromegaly. Pituitary. 2002;5(1):21-5.

58. Projeto Diretrizes. Associação Médica Brasileira e Conselho Federal de Medicina. [cited nov 8, 2009] Available from: www.projetodiretrizes.org.br. 